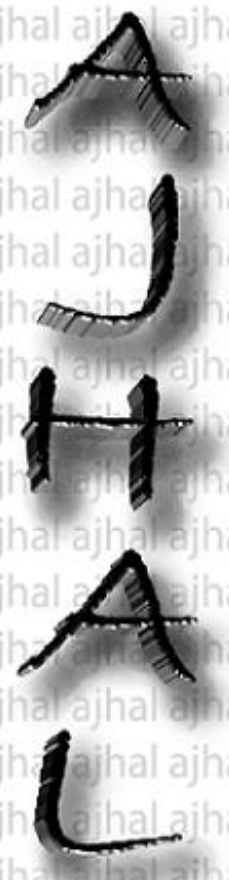

[SSN 2314-8636

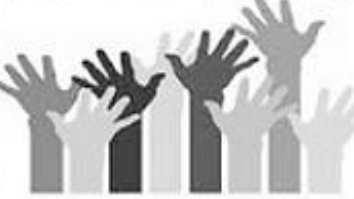

THERET5ாם 토月P工田

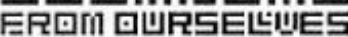
잩 HШாПП 코느ㅌㅣㅐㅛ

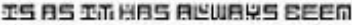
月กㅋ 트 5ㅁㄴㅃㅌㅡ

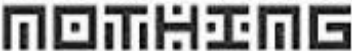

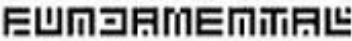

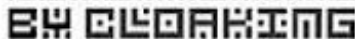
口URSE느트

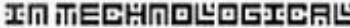
Б늠ㅁㅍㅜ Vol 3, No. 1/2016

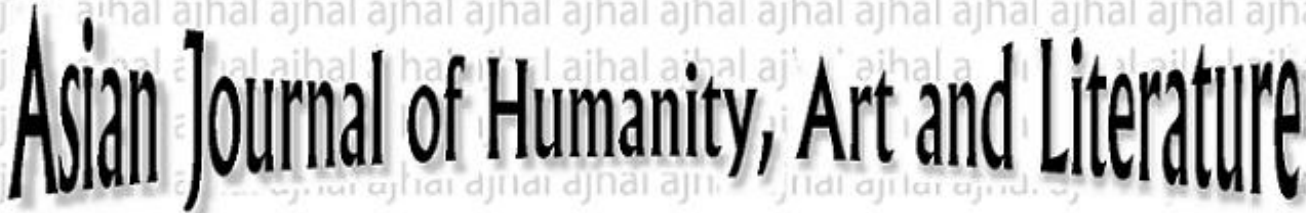




\section{Assessment of the Process of Recruitment of School Evaluators for Primary Schools in South East, Nigeria}

ISSN: 2311-8636 (Print) ISSN: 2312-2021 (Online)

DOI prefix: 10.18034/ajhal

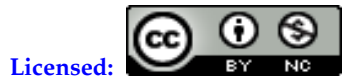

Source of Support: Nil

Conflict of Interest: None Declared

${ }^{*}$ Email for correspondence:

ifeyinwa.ezenwaji@unn.edu.ng

\section{O. Ezenwaji Ifeyinwa}

Department of Educational Foundations, Faculty of Education, University of Nigeria, Nsukka, Enugu State, NIGERIA

\section{ABSTRACT}

Inadequate and use of unqualified and untrained personnel in the inspectorate services resulting in poor quality output in the school system has created a gap in teachers' preparation and update in Nigerian evaluators. Meaningful and quality education can only be achieved with the guide and check of qualified and modern evaluators. The article attempts to find out how criteria for recruitment of evaluators are adhered to and problems the evaluators encounter in their practices as evaluators in South East,

Nigeria and proffer solution. A descriptive survey was adopted for the study, two research questions and two null hypotheses, tested at $(\mathrm{p}<.05)$ level of significance, were used. Through a multistage procedure, three out of the five states were selected from the south-east zone. 371 head-teachers from public primary schools and 257 evaluators of the inspectorate services were sampled. A 38 items questionnaire titled. Primary school Assessment questionnaire (PSAQ), covering different areas of school evaluation was developed by the researcher to get information from respondents, the head teachers and the evaluators. The finding of the study showed that there is significant difference between the mean rating of evaluators and head teachers with regards to the application of criteria guiding the recruitment of evaluators. The Government should also develop a new programme for the unit.

Key Words: appraisal, evaluators, primary schools

\section{INTRODUCTION}

The desire for a sustainable development of any nation, including Nigeria, especially in the area of quality education cannot be realized without a concerted and sustained effort at, improving the quality of inspection and supervision. For teaching and learning to be meaningful and efficient the learner must be exposed to sound, responsive, relevant and meaningful quality education at all levels of the education system. Standard and quality education can be achieved only with the guide and check of qualified and experienced inspectors currently known as evaluators. It was recent that the name inspector was changed to the evaluator as a result of the stigma that the name inspector carries. Though the name has been changed, the unit and their functions remain.

According to the Federal Ministry of Education (FME) (2009), an education evaluator is an authorised official of the Ministry of Education who identifies and provides feedback on 
strengths and weaknesses in educational institutions so that these institutions can improve the quality of education provided and the achievements of their learners. In this work, evaluator, inspector and quality assurance agents will be used interchangeably. The Federal Republic of Nigeria (FRN) (2012) in her National Policy on Education stated that the success of any system of education is hinged on proper planning, efficient administration and adequate financing. It stated further that administration is a function of organization and structure, proprietorship and control, inspection and supervision.

Inspection and supervision are essential activities of any organization. Ogunsaju (1983) noted that both have almost the same administrative function. Scholars and researchers often used inspection and supervision interchangeably, but despite their similarities, there is still a difference between the two concepts. Inspection is all about the total and general assessment of the educational programme, with the aim of finding solutions to educational problems, while supervision is all about helping teachers to improve instructional delivery. Buttressing the above fact, Olagboye (2004) noted that the term "inspection" is older in the field than supervision. Inspection is a term that has been in existence from the time of the colonial masters, even during the missionary era when schools were managed by the missionaries. School inspection is an official visit that is directed at finding out problems encountered by teachers, head-teachers and school personnel with a view to finding solutions to these problems so that the standard of education can be maintained. (Universal Basic Education Programme (UBEP, 2002).

From the above definition of inspection, one now begin to imagine the calibre of individuals to carry out this costly and sensitive exercise, which if carried out well, will bring quality and standard to the educational system while the mismanagement of the function can ruin the whole system. Aghanta (2006) noted that trained and educated human resources contribute positively to manpower and personnel needed to bring about national development. It, therefore, means that the quality of education received by the citizen determines the level of development of any nation. Being aware of the importance of school inspection and the sensitive nature of the job, the criteria utilized for the recruitment and selection of the personnel are very important as the quality of service depends on the calibre of the people recruited to do the job. The Federal Inspectorate Services (FIS) is a division of the Federal Ministry of Education (FME), charged with the responsibility of seeing to it that inspection is carried out in schools. The staff of the FIS are deployed to Federal Capital office while some to each of the state capitals where they perform their functions in collaboration with their state counterparts and report back to the headquarter.

Previously, the selection of inspectors/evaluators for the schools was based on basic qualification that must also include educational courses, experience in teaching for at least ten years. Recently, the recruitment of all evaluators is a prerogative of the Federal Inspectorate service, state inspectorate service and Local Government Education Authority (LGEA). (FME, 2010). The office for standards in Education Britain (OFSTED) (2005) stated that evaluators should be properly trained and assessed to specific standards with their initial training lasting for several months. The office further observed that even when evaluators have been recruited, they should still engage in continuous professional development to improve their monitoring skills.

As mentioned earlier, the recruitment of evaluator is crucial as the quality of the service depends on calibre of those appointed to carry out the job of monitoring and evaluation. Oguno (2011) observed that recruitment of evaluators does not seem to take cognizance of the right qualities required for effective performance. Secondly, the criteria for appointment of evaluators are basically the possession of a first degree in education and some years of teaching experience. In some cases, owing to acute shortage of evaluators, 
some teachers without the required level of education and teaching experience are recruited as evaluators. It is worth knowing that if people employed to do the work of monitoring do not have the necessary qualification and exposure needed for their crucial role in ensuring quality education in the school system, the needed quality and standard will not be achieved and the aim of the inspectorate unit will not be justified.

In Kenya, for instance, Wasanaga (2004) noted, the modalities for identifying potential quality assurance personnel are based on the track records of the applicant in relation to previous and present performance. Wasanaga stated further that the applicant should be a degree holder with at least 3 years teaching experience, and evidence of potential in quality assurance in education courses. Similarly, Ochuba (2001) stated that; a good evaluator should, therefore, have the appropriate qualification and experience. It is also important that such evaluator should be able to write comprehensive and accurate reports based on information collected with the instrument. Furthermore, the evaluator should be able to collect, collate and analyze data that are part of the job requirement of the inspectorate services.

Fagbamiye (2009) noted that lack of accurate and timely data has long been the bane of policy formulation and management of primary education system in Nigeria. To obtain accurate data on enrolment, teachers, non-teaching staff and even facilities appear to be a difficult task for school evaluators. The evaluators and teachers seem to lack adequate cognitive development in the area of data collation, analysis and storage.

Emphasising the importance of the job of an evaluator in the area of data management and cognitive development in data collection and analysis, the need to re-assess the process of the recruitment of educational evaluators popularly known as inspectors became an issue. An issue in the sense that modern evaluators with ICT based knowledge need to replace the old evaluators in the system to help bring quality teaching and learning in schools.

Assuring quality is a major challenge in the Nigerian educational system. From the observable infrastructural decay, declining standards, cultism, examination malpractice, maladministration as well as facts and statistics from the 2006 general inspection of 14, 942 secondary school nation-wide, it is obvious that the state of education in Nigeria is poor, necessitating urgent remedial actions (FME, 2009).

From the above assertion one can deduce that the situation is not better in public primary schools; the declining standard is every where, especially in public primary schools. The performance of inspectorate unit at the three tiers of government has been considerably poor. It is worth knowing that in Nigeria, the current model of monitoring schools which was inherited from the colonial government has remained unchanged despite the changing circumstances in the country. The Nigerian method of monitoring has refused to be dynamic in its mode and practice. Currently, Nigeria is experiencing a severe lack and shortage of Information Communication Technology (ICT) skilled personnel in FIS necessary for taking advantage of new and emerging technologies in the knowledge society.

The FIS, in pursuit of quality and innovation, came up with what is known as quality assurance frame work, which tries to address the major issues that underpin the operations of the quality assurance body. The body adopted the whole school evaluation model as the major innovation for conducting quality assurance activities in Nigerian schools. The development of a framework is good and a credit to the inspectorate unit but for the operation of the framework to work for the good of the nation depend on the operators involved. In this era of science and technology, for any innovation to take place, the qualification and training of the implementers is of vital importance. Looking at the Nigerian evaluators, we discover that most education evaluators, have no special training to carry out their functions; the recruitment is based on the years of experience as a teacher and the years of service, in some cases teachers that have not reached the required level 
may be co-opted to serve as a result of the number of schools to cover, in some cases, retired inspectors and other senior educationists may be invited to apply, trained and accredited as demand arises.

According to the quality assurance hand book of the FIS, for one to become an accredited external evaluator and carry out external evaluations, individuals must have successfully pass through a process of selection, training, assessment and probation before finally accredited.

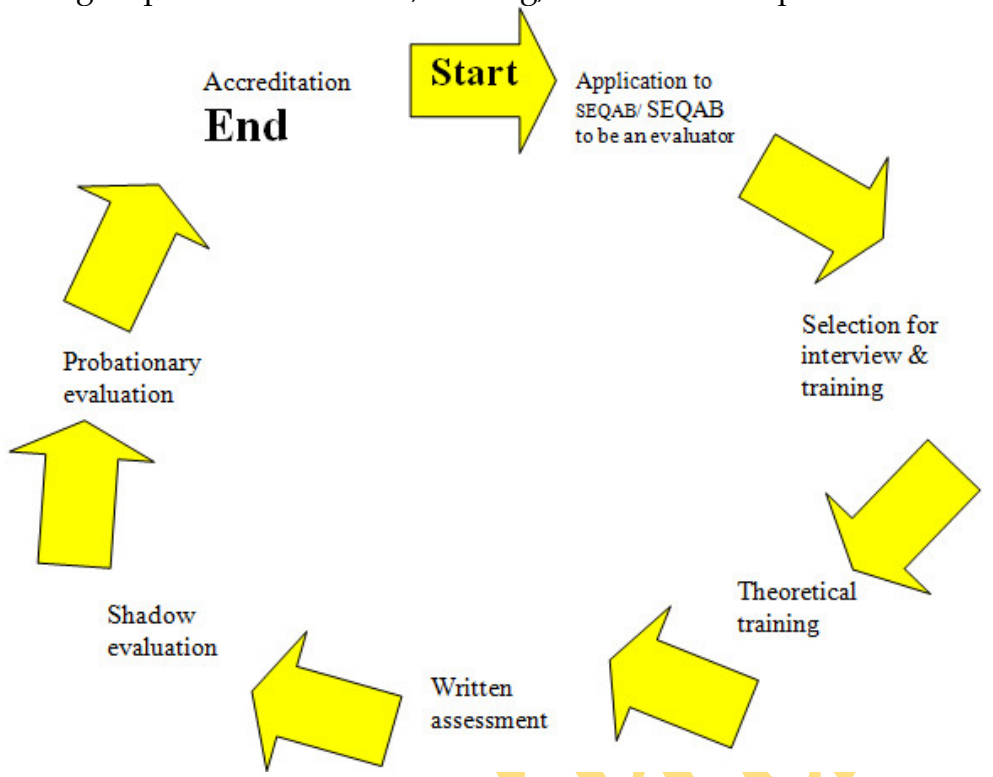

Source: Quality Assurance Hand book pg: 52

Key = NEQAB-National Education Quality Assurance Body SEQAB -State Education Quality Assurance Body

Above is the accreditation process. Looking at the process of the accreditation, the researcher feels that the process appear not to take cognizance of the sensitive duty of an evaluator as a quality assurance agent, the course of the study, the number of months and years the training will take, the curriculum content and the modern techniques of evaluation which the training will cover. Also, the number of evaluators that will benefit from the training, and the qualification and the calibre of the personnel in charge of the training, whether the programme is meant to fulfil all righteousness.

The modern method and techniques of monitoring and evaluation appear not to be put into consideration. For modern method of monitoring and evaluation to work fully in a developing nation like Nigeria, a new programme need to be drawn for training of new evaluators and the recruitment exercise will take effect as soon as they graduate from the university and not for prospective evaluators to have served for many years in the school system as stipulated in the criteria for recruitment. Evaluators are expected to be recruited and selected when young and productive, not when an individual is almost of retirement age, the selection will now take place. Looking at Peter's Principle, in occupation incompetence and the study of hierarchies, employees appear competent in their position when promoted and their competence in each new position qualifies them for promotion to the next highest position until a position of incompetence is reached (Peter 2007) Peter (2007) stated that from teaching occupation Mr. C is a competent and conforming college teacher and head of a department, is promoted to assistant principal, and being intellectually competent, he is further promoted to principal. Mr. C is now 
required to put in the best to improve learning, but the reverse is the case because $\mathrm{Mr}$. $\mathrm{C}$ has no energy to work and make progress because Mr. C has reached the level of incompetence.

From the illustration above, there is the need to review the criteria for selection and recruitment of school evaluators. Government is expected to develop a new programme for young university graduates who will take over the job of inspection of schools and those outdated evaluators retired or posted out of the inspectorate for standard and quality to be achieved in the educational system, especially in public primary schools.

The performance of pupils in public primary schools is not encouraging compared to the pupils in good private school. This might be because the owners of the private schools do a serious monitoring of the progress of the schools in question. What goes on in many public primary schools in south-east zone of Nigeria calls for attention of the quality assurance agents of FIS. Public primary schools are those primary schools owned and managed by the government. One seldom hears of inspectors of education today who actually go round and ensure good standard and quality education.

On the problem militating against effective primary school monitoring, Ogbonnaya (2004) observed that evaluators lack relevant materials, tools and resources for effective execution of their functions such as current journals, textbooks, periodicals among others. Nnadozie (2001) stated that financial inadequacies have been the basic factor militating against the planning and implementation of inspectional programmes. There is the need for the right quantity and quality of evaluators to ensure regular visits to schools. The expected outcome is improved quality of education. This study is, therefore, to assess the process of recruitment of education evaluators, popularly known as inspectors.

\section{PuRPose OF THE StUdY}

The main purpose of the study was to assess the process of recruitment of school evaluators in South East Nigeria. The study examined

- The extent to which the criteria for recruitment of evaluators are adhered.

- Problems confronting evaluators in primary schools monitoring and evaluation.

\section{ReSEARCH Questions}

- To who extent are the criteria for recruitment of evaluators adhered to.

- What are the problems confronting evaluators in carrying out primary school monitoring/ and evaluation

\section{HYPOTHESES}

Two null hypotheses were formulated and tested at 0.05 level of significance guided the study.

$\mathrm{H0}$ : There is no significance difference between the mean ratings of evaluators and head teachers on the extent of adherence to the criteria for the recruitment of evaluators in South East Nigeria.

$\mathrm{H}_{2}$ : There is no significance difference between the mean rating of evaluators and head teachers on the problems confronting evaluators in public primary schools monitoring in South East Nigeria.

\section{SIGNIFICANCE}

The findings of this study will be of immense importance to the Federal Ministry of Education, Inspectorate unit, quality assurance agents (evaluators) and the head teachers of public primary schools in South East Nigeria. The findings will help the nation to see the need for regular monitoring of schools and the relevance. The ministries of education both at the federal and state level will look into the criteria for recruitment of evaluators 
and see the need to draw a special programme for it. Evaluators and head teachers will see the need to work hand in hand and improve the standard of teaching and learning in public primary schools to enable them compete with their private counterparts.

\section{Methodology}

The study adopted descriptive survey research design. The population of the study was 5,973, comprising 5,627 head teachers of public primary schools and 346 evaluators in the state ministries of education in South East Nigeria. Through multistage sampling technique, three states were randomly sampled out of the five states, representing $60 \%$ of the population. The three states are Anambra, Enugu and Imo. The three states have a total of 3,712 head teachers: Anambra 1,260, Enugu 1,180 and Imo 1,272 and a total of 257 evaluators: Anambra 155, Enugu 72 and Imo 30. Out of the 3,712 head teachers, $10 \%$ were selected through simple random sampling technique which gave a total of 371 head teachers. On the side of the evaluators, all the 257 evaluators were used for the study, there was, therefore, no sampling of the evaluators. The total number of respondents were therefore 628 made up of 371 head teachers and 257 evaluators. A 38-item questionnaire titled "Primary School Assessment Questionnaire" (PSAQ) was used for the study. PSAQ has 2 clusters, A and B. Cluster A elicited information on the extent of adherence to the criteria for recruitment of evaluators while cluster B addressed the problems the evaluators encounter in their practices. Three experts validated the instruments two from Educational Management, and one from Measurement and Evaluation all from the Faculty of Education, University of Nigeria, Nsukka. The internal reliability estimate of the clusters was 0.92 and 0.76 respectively. The questionnaire had an overall reliability index of 0.97 computed using Cronbach Alpha method. Three research assistants were used to administer the instrument through direct delivery method. Descriptive statistics was used to analyse the data while t-test statistics was used in testing the hypotheses at 0.05 probability level.

\section{RESULTS}

Research Question 1: What is the extent of adherence to criteria for the recruitment of evaluators? The data for providing answer to the research question 1 above is presented on Table 1 below:

Table 1: Mean and Standard deviation of inspectors and head-teachers on recruitment of inspectors

\begin{tabular}{|c|c|c|c|c|c|c|c|}
\hline \multirow[t]{2}{*}{$\begin{array}{l}\mathbf{S} / \\
\mathbf{N}\end{array}$} & \multirow[t]{2}{*}{ Criteria for recruitment } & \multicolumn{2}{|c|}{$\begin{array}{l}\text { Evaluators } \\
N=257\end{array}$} & & \multicolumn{3}{|c|}{$\begin{array}{l}\text { Head-Teachers } \\
N=371\end{array}$} \\
\hline & & $\bar{x}$ & SD & DEC & $\bar{x}$ & SD & DEC \\
\hline 1 & $\begin{array}{l}\text { Evaluators' academic and professional } \\
\text { qualifications. }\end{array}$ & 2.86 & 0.85 & GE & 2.64 & 1.01 & GE \\
\hline 2 & $\begin{array}{l}\text { The evaluators' output as a teacher is } \\
\text { considered before being selected. }\end{array}$ & 2.25 & 0.85 & LE & 2.77 & 0.89 & GE \\
\hline 3 & $\begin{array}{l}\text { The evaluators' subject area of } \\
\text { specialization. }\end{array}$ & 2.53 & 0.87 & GE & 2.39 & 1.10 & LE \\
\hline 4 & $\begin{array}{l}\text { Political leanings of the evaluators' are } \\
\text { considered. }\end{array}$ & 2.39 & 0.75 & LE & 2.57 & 1.04 & GE \\
\hline 5 & $\begin{array}{l}\text { Evidence of potentials in evaluators' } \\
\text { training courses is considered }\end{array}$ & 1.69 & 0.81 & LE & 1.99 & 0.89 & LE \\
\hline 6 & $\begin{array}{l}\text { Selected evaluators' must have spent a } \\
\text { minimum of ten years as a teacher }\end{array}$ & 2.82 & 0.87 & GE & 2.66 & 1.02 & GE \\
\hline \multirow[t]{2}{*}{7} & $\begin{array}{l}\text { The selection of evaluators is based on } \\
\text { need in the area or available vacancies. }\end{array}$ & 2.57 & 0.91 & GE & 2.73 & 1.00 & GE \\
\hline & Cluster $\bar{x}$ & 2.44 & 0.41 & LE & 2.54 & 0.65 & GE \\
\hline
\end{tabular}


The results in Table 1 showed that, of the 7 items on the extent to which the Ministries of Education adhere to criteria on the recruitment of evaluators, four of the items, namely items; 1,3,6 and 7, which were on evaluators academic and professional qualifications, evaluators area of specialization, minimum of ten years of experience as a teacher, and available vacancies were rated great extent by the evaluators, $(\bar{x}=2.86,2.53,2.82$ and 2.57). Items 2,4 and 5 which were on the evaluators' output as a teacher before being selected, $(\bar{x}=2.25)$, political leanings of the evaluator $(\bar{x}=2.39)$ and evidence of potentials on evaluators training courses were rated low extent by the same evaluators.

The table also showed that items $1,2,4,6$ and 7 were rated great extent by Head-Teachers, $(\overline{\times}=2.64$, $2.77,2.66$ and 2.73) while, the head - teachers rated items 3 and 5 little extent which were on the evaluators subject area of specialization $(\bar{x}=1.69, \mathrm{SD}=0.81)$, and evidence of potentials on evaluators training courses is considered $(\bar{X}=1.99$, SD 0.89$)$ respectively.

\section{Research Question 2}

What are the problems confronting evaluators in monitoring public primary schools in South East zone of Nigeria?

This research question was answered using data collected from Table two below:

Table 2: Mean and Standard deviation on problems confronting evaluators in carrying out school monitoring.

\begin{tabular}{|c|c|c|c|c|c|c|c|}
\hline \multirow[t]{2}{*}{$\mathbf{S} / \mathbf{N}$} & \multirow[t]{2}{*}{ Constraining factor items } & \multicolumn{2}{|c|}{$\begin{array}{l}\text { Evaluators } \\
\mathrm{N}=257\end{array}$} & \multicolumn{4}{|c|}{$\begin{array}{l}\text { Head-Teachers } \\
\mathbf{N}=371\end{array}$} \\
\hline & & $\bar{x}$ & SD & DEC & $\bar{x}$ & SD & DEC \\
\hline 8 & $\begin{array}{l}\text { Most of the serving evaluators are above } \\
45 \text { years considering the length of service. }\end{array}$ & 3.11 & 0.99 & A & 3.11 & 0.93 & A \\
\hline 9 & $\begin{array}{l}\text { No specific curriculum for the training of } \\
\text { evaluators }\end{array}$ & 2.74 & 0.96 & $\mathrm{~A}$ & 3.16 & 0.84 & A \\
\hline 10 & $\begin{array}{l}\text { Most of the good policies of the } \\
\text { inspectorate are never implemented. }\end{array}$ & 3.28 & 2.89 & A & 2.95 & 0.93 & A \\
\hline 11 & $\begin{array}{l}\text { Funds allocated to the inspectorate are } \\
\text { never enough. }\end{array}$ & 3.15 & 0.59 & A & 3.06 & 0.67 & A \\
\hline 12 & $\begin{array}{l}\text { Inappropriate selection of primary school } \\
\text { evaluators. }\end{array}$ & 2.91 & 2.84 & A & 3.19 & 0.83 & $\mathrm{~A}$ \\
\hline 13 & Poor job description for inspectors. & 2.39 & 0.77 & $\mathrm{D}$ & 2.62 & 0.90 & A \\
\hline 14 & $\begin{array}{l}\text { Lack of professionally trained personnel to } \\
\text { carry out school monitoring. }\end{array}$ & 2.16 & 1.02 & $\mathrm{D}$ & 2.16 & 1.04 & $\mathrm{D}$ \\
\hline 15 & $\begin{array}{l}\text { The poor motivation of evaluators to } \\
\text { enhance effectiveness. }\end{array}$ & 3.21 & 0.74 & A & 3.14 & 0.79 & A \\
\hline 16 & $\begin{array}{l}\text { Poor staff development programme to } \\
\text { acquaint evaluators with recent } \\
\text { developments on school monitoring. }\end{array}$ & 2.94 & 0.84 & A & 2.93 & 0.88 & A \\
\hline 17 & Lack of materials for effective monitoring. & 2.71 & 1.09 & A & 3.12 & 0.80 & A \\
\hline 18 & Lack of vehicles to embark on inspection visit. & 3.26 & 0.64 & A & 3.17 & 0.82 & A \\
\hline \multirow[t]{2}{*}{19} & $\begin{array}{l}\text { Evaluators' reports are never taken } \\
\text { seriously by the government. }\end{array}$ & 2.34 & 0.64 & $\mathrm{D}$ & 3.17 & 0.83 & A \\
\hline & Cluster $\times$ & 2.93 & 0.57 & A & 3.03 & 0.40 & A \\
\hline
\end{tabular}

Table 2 above indicates the means rating of evaluators and heads teachers on the problems militating against effective school monitoring. Items 8, 9, 10, 11, 12, 15, 16, 17 and 18 were rated agreed by both the evaluators and Head-teachers. These items were, that people at the top do 
not allow the evaluators to contribute their ideas on policy making, $(\bar{x}=3.11$ and 3.11), permission for any major innovation is required of the evaluators from the Ministry $(\bar{x}=2.74$ and 3.16), most of the good policies of the inspectorate are never implemented $(\bar{x}=3.28$ and 2.95), funds allocated to the inspectorate are never enough $(\bar{x}=3.15$ and 3.06) evaluators are inappropriately selected $(\bar{x}=2.91$ and 3.19 ). Others were poor motivation of evaluators, poor staff development programmes to acquaint evaluators with recent development on school monitoring ( $\bar{x}=2.94$ and 2.93) evaluators' lack of materials for effective monitoring, $(\bar{x}=2.71$ and 3.12) lack of vehicles to embark on inspection visit $(\bar{X}=3.26$ and 3.17). The evaluators and head-teachers indicated that lack of professionally trained personnel is not among the problems militating against effective monitoring in the public primary schools, while the evaluators indicated that poor job description for evaluators $(\bar{x}=2.39)$ and non-utilization of evaluators' reports by the government $(\bar{x}=2.34)$ were not among factors militating against effective primary school monitoring.

Table 3 Independent: $t$-test of the difference between the mean ratings of evaluators and head-teachers on the application of criteria guiding the recruitment of evaluators.

\begin{tabular}{|c|c|c|c|c|c|c|c|}
\hline \multirow[t]{2}{*}{$\begin{array}{l}\mathrm{S} / \\
\mathrm{N}\end{array}$} & \multirow[t]{2}{*}{ Questionnaire Item } & \multicolumn{2}{|c|}{$\begin{array}{l}\text { Evaluators } \\
\mathrm{N}=257\end{array}$} & \multicolumn{2}{|c|}{$\begin{array}{l}\text { Head-Teachers } \\
\mathrm{N}=371\end{array}$} & \multirow[t]{2}{*}{ t-cal } & \multirow[t]{2}{*}{$\begin{array}{l}\mathrm{t} \text {-critical } \\
\text { value }\end{array}$} \\
\hline & & $\bar{x}$ & SD & $\bar{x}$ & SD & & \\
\hline 20 & $\begin{array}{l}\text { Evaluators' academic and } \\
\text { professional qualifications. }\end{array}$ & 2.86 & 0.85 & 2.64 & 1.01 & 2.89 & 1.96 \\
\hline 21 & $\begin{array}{l}\text { The evaluators' output as teachers } \\
\text { is considered before being selected. }\end{array}$ & 2.25 & 0.85 & 2.77 & 0.89 & 6.97 & 1.96 \\
\hline 22 & $\begin{array}{l}\text { Political leanings of the inspectors } \\
\text { are considered. }\end{array}$ & 2.39 & 0.75 & 2.57 & 1.04 & -2.35 & 1.96 \\
\hline 23 & $\begin{array}{l}\text { The evaluators' subject area of } \\
\text { specialization. }\end{array}$ & 2.53 & 0.87 & 2.39 & 1.10 & 1.70 & 1.96 \\
\hline 24 & $\begin{array}{l}\text { Evidence of potentials on inspector } \\
\text { training courses is considered. }\end{array}$ & 1.69 & 0.81 & 1.99 & 0.89 & -4.19 & 1.96 \\
\hline 25 & $\begin{array}{l}\text { Selected evaluators' must have put } \\
\text { in a minimum of ten years as } \\
\text { teachers. }\end{array}$ & 2.82 & 0.87 & 2.66 & 1.02 & 1.99 & 1.96 \\
\hline \multirow[t]{2}{*}{26} & $\begin{array}{l}\text { The selection of evaluators is based } \\
\text { on need in the area or available } \\
\text { vacancies. }\end{array}$ & 2.57 & 0.91 & 2.73 & 1.00 & -2.08 & 1.96 \\
\hline & Cluster $\bar{x}$ & 2.44 & 0.41 & 2.51 & 0.65 & -1.97 & 1.96 \\
\hline
\end{tabular}

The table shows that the $t$-calculated value -1.97 , is less than $t$-critical value 1.96 . so there is statistically significant difference between the mean ratings of evaluators and headteachers on basic requirement for recruitment of evaluators. And so the null hypothesis is rejected. On items by item analysis, items 28, 29, 30, 32, 33 and 34 have t-calculated of 2.89, $6.97,-2.35,-4.19,1.99$ and -2.08 . So there is statistically significant difference between the mean ratings of evaluators and head-teachers with regards to the extent required for recruited of evaluators. 
Table 4 Independent: t-test analysis on problems confronting inspectoral functions in public primary schools.

\begin{tabular}{|c|c|c|c|c|c|c|c|}
\hline \multirow[t]{2}{*}{$\mathbf{S} / \mathbf{N}$} & \multirow[t]{2}{*}{ Constraining factor items } & \multicolumn{2}{|c|}{$\begin{array}{l}\text { evaluators } \\
\mathbf{N}=257\end{array}$} & \multicolumn{2}{|c|}{$\begin{array}{l}\text { Head-Teachers } \\
\mathrm{N}=371\end{array}$} & \multirow[t]{2}{*}{ t-cal } & \multirow[t]{2}{*}{$\begin{array}{l}\text { t-critical } \\
\text { value }\end{array}$} \\
\hline & & $\bar{x}$ & SD & $\bar{x}$ & SD & & \\
\hline 27 & $\begin{array}{l}\text { Most of the serving evaluators are } \\
\text { above } 45 \text { years considering the length } \\
\text { of service. }\end{array}$ & 2.74 & 0.96 & 3.16 & 0.84 & -5.37 & 1.96 \\
\hline 28 & $\begin{array}{l}\text { No specific curriculum for the } \\
\text { training of evaluators }\end{array}$ & 3.11 & 0.99 & 3.11 & 0.93 & -.00 & 1.96 \\
\hline 29 & $\begin{array}{l}\text { Most of the good policies of the } \\
\text { inspectorate are never implemented. }\end{array}$ & 3.28 & 2.89 & 2.95 & 0.93 & 1.67 & 1.96 \\
\hline 30 & $\begin{array}{l}\text { Funds allocated to the inspectorate } \\
\text { are never enough. }\end{array}$ & 3.15 & 0.59 & 3.06 & 0.67 & 1.74 & 1.96 \\
\hline 31 & $\begin{array}{l}\text { Inappropriate selection of primary } \\
\text { school evaluators. }\end{array}$ & 2.91 & 2.84 & 3.19 & 0.83 & -1.44 & 1.96 \\
\hline 32 & Poor job description for evaluators. & 2.39 & 0.77 & 2.62 & 0.90 & -3.32 & 1.96 \\
\hline 33 & $\begin{array}{l}\text { Lack of professionally trained } \\
\text { personnel to carry out school } \\
\text { monitoring. }\end{array}$ & 2.16 & 1.02 & 2.16 & 1.04 & -5.42 & 1.96 \\
\hline 34 & $\begin{array}{l}\text { Poor motivation of evaluators to } \\
\text { enhance effectiveness. }\end{array}$ & 3.21 & 0.74 & 3.14 & 0.79 & 1.08 & 1.96 \\
\hline 35 & $\begin{array}{l}\text { Poor staff development functions to } \\
\text { acquaint evaluators with recent } \\
\text { developments on school monitoring. }\end{array}$ & 2.94 & 0.84 & 2.93 & 0.88 & 0.11 & 1.96 \\
\hline 36 & $\begin{array}{l}\text { Evaluators lack materials for effective } \\
\text { monitoring. }\end{array}$ & 2.71 & 1.09 & 3.12 & 0.80 & -4.78 & 1.96 \\
\hline 37 & $\begin{array}{l}\text { Lack of vehicles to embark on } \\
\text { inspection visit. }\end{array}$ & 3.26 & 0.64 & 3.17 & 0.82 & 1.44 & 1.96 \\
\hline \multirow[t]{2}{*}{38} & $\begin{array}{l}\text { Evaluators' reports are never taken } \\
\text { serious by the government. }\end{array}$ & 3.34 & 0.64 & 3.17 & 0.83 & 1.54 & 1.96 \\
\hline & Cluster $\bar{x}$ & 2.93 & 0.57 & 3.03 & 0.40 & -2.25 & 1.96 \\
\hline
\end{tabular}

The data on Table 4 indicated that all the 12 items on the table had calculated $t$-value less than the critical value of 1.96. Therefore, there is no significant difference between the opinions of evaluators and head-teachers on the problems militating against effective inspection in public primary schools with respect to the items.

\section{DisCUSSION OF RESULTS}

The findings of the study indicated that evaluators and head teachers agreed that, to a great extent, recruitment of evaluators is based on evaluators' selection criteria that include academic and professional qualifications, evaluators having a minimum of ten years teaching experience. The criteria for recruitment of evaluators are crucial as the quality of service depends on competences of those recruited. According to Ogonu (2001), the criteria for appointment of evaluators is basically the possession of first degrees in education with some years of teaching experience without considering other important areas like the evaluators output as teachers. Secondly, as a result of acute shortage of evaluators, some teachers without the requisite experience are recruited as evaluators, thus not adhering to the necessary qualification and experience needed for the crucial role of ensuring quality education in school.

The analysis of hypothesis 1 (table 3) revealed that there is no significant difference between the mean ratings of evaluators and head-teachers on the criteria for recruitment of evaluators in primary schools in South-East Zone of Nigeria. The data shows that the overall $t$-value, which is -1.97 is less than the critical $t$-value, therefore the null hypothesis is not rejected. This implies that position or status is not a factor in their perception. 
With reference to research question two, the respondents (evaluators and head teachers) agreed unanimously that the problems militating against effective inspection in public primary schools include the following: most of the serving evaluators are no longer young to be desperate to search for new knowledge like a fresh graduate from the University, no particular curriculum for evaluators' training, funds allocated to the inspectorate are never enough, evaluators are poorly motivated, poor staff development programme to support staff, lack of materials for effective monitoring, lack of vehicles to embark on monitoring exercise, evaluators' reports are never taken seriously by the government.

The finding agrees with Ogbonnaya (2004) who observed that evaluators lack relevant materials, tools and resources for effective execution of their functions such as journals, textbook, periodicals among other. Nnadozie (2001) stated that financial inadequacies have been the basic factor militating against the planning and implementation of inspectoral programmes in Nigeria.

\section{CONCLUSIONS}

Quality assurance and maintenance of standard have been the desire and wish of every developing nation including Nigeria. The search for quality education has led the FIS to search for new ideas and innovation, which if implemented and religiously applied, the standard will be improved. From the findings and discussions of the study, the following conclusions are made; criteria in the recruitment of evaluators should be strictly adhered to, a new programme should be drawn for the unit, and those serving already should be properly inducted or posted out of the inspectorate.

\section{RECOMMENDATIONS}

Primary school evaluators should be selected not only considering academic and professional qualifications and available vacancies, but other variables like the candidates age should be seriously taken into consideration.

If the problem of not adhering strictly to the criteria in recruitment is not solved, it could deter some evaluators from carrying out their duties effectively in schools, it may also discourage some teachers and head teachers from putting in their best, thus impeding the overall educational objectives.

Primary school evaluators should be strictly selected not only considering accepted norms such as academic and professional qualifications, available vacancies but other aspects like the candidates' output as teachers, the track record of the candidates in relation to previous and present performances, evidence of potentials on evaluator's training courses and the candidates knowledge on subject matter, pedagogy and psychology amongst others.

The government should also develop a new programme for fresh graduates from the university to serve as evaluators in the inspectorate unit.

\section{REFERENCES}

Abdullah, A., \& Hossain, M. (2014). Brain Drain: Economic and Social Sufferings for Bangladesh. Asian Journal Of Humanity, Art And Literature, 1(1), 9-17.

Aghenta, J. A 2006: Human resource development and planning in Nigeria. Second Faculty of Education distinguished lecture series, University of Benin, Benin City.

Fagbamiye, E. O (2009): Management of primary and secondary education in Nigeria. NAEAP publication. Retrieved from www.academicjournals.org/jgrp/PDF/.../OLAMIJU\%20and\%20OLUJIMI.p.

Federal Ministry of Education (2001). Inspectors manual. The Federal Inspectorate Service.

Federal Ministry of Education. Draft inspectors handbook for inspection of educational institutions in Nigeria, (2009-2010).

Federal Republic of Nigeria (1981). National policy on education. Lagos: Federal Ministry of Information.

Federal Republic of Nigeria (1985). National minimum standard and establishment of institutions, Decree No. 16.

Federal Republic of Nigeria. (2004). National policy on education ( $4^{\text {th }}$ Edition). Lagos: NERDC Press.

Gebrehiwot, K. (2014). The Impact of Human Capital Development on Economic Growth in Ethiopia: Evidence from ARDL Approach to Co-Integration. American Journal Of Trade And Policy, 1(3), 125-134. 
Lerra, M. (2014). The Dynamics and Challenges of Distance Education at Private Higher Institutions in South Ethiopia. Asian Journal Of Humanity, Art And Literature, 1(3), 137-149.

Masanja, M., \& Msuya, J. (2014). Social Changes Imposed by HIV and AIDS in Rural Areas: An Empirical Evidence of Sex Education in Maswa District, Tanzania. Asian Journal Of Applied Science And Engineering, 3(3), 309-320.

Mitiku, W., Alemu, Y., \& Mengsitu, S. (2014). Challenges and Opportunities to Implement Inclusive Education. Asian Journal Of Humanity, Art And Literature, 1(2), 118-135.

Nnadozie, J.C (2001) Critical Historical antecedents of Universal Basic Education Journal of Universal Basic Education, 1 (2), 232-237.

Ochuba, V. O 2009: Improving the quality of education in Nigeria through effective inspection of schools. Find article.com. Retrieved from www2.warwick.ac.uk/fac/soc/wie/courses/degrees/docs/.../teaching/

Office for Standards In Education (OFSTED). (2005): Framework for the inspection of schools in England. OFSTED.

Ogbonnaya N.O. (2004). Introduction to Inspection and Supervision. Unpublished Lecture Note Department of Educational Foundations UNN.

Ogbonnaya, N. (2004). Evaluation of the administration of the sandwich programme of two Universities in South Eastern Nigeria. (doctoral dissertation, University of Nigeria Nsukka, 1990).

Ogunsaju, S (2006) School management and supervision. Ile-Ife: Clean Put Publishers.

Ogunu, M. A (2000). Introduction to educational management. Benin City: Mabogun Publishers.

Ogunu, M. A (2001) Problems of school inspection in Nigeria. In N. A Nwagwu, (ed) current issues in educational management in Nigeria. Nigeria association of educational administration and planning.

Olagboye (2004). My teaching: school inspection for improvement. Retrieved from www2.warwick.ac.uk/fac/soc/wie/courses/degrees/docs/.../teaching/

Peter, L.J. (1970). The Peter Principle, Pan Books. In Laurie. J. Mullins (2007). Management and Organizational Behaviour. Person Education Ltd. Edinburgh Gate, Harlow. England

Tsegaye, M., \& Moges, B. (2014). Roles And Challenges of Secondary School Instructional Leadership for the Achievement of Student Learning: The Case of South Gondar Administrative Zone, Amhara Region, Ethiopia. Asian Journal Of Humanity, Art And Literature, 1(1), 48-69.

Wasanaga, P. M. (2004). Quality assurance in basic education. A position paper at the UNESCO Nairobi cluster consultation on quality standards and quality assurance in basic education, Kenya: 6-8 December. 
Archive: https://i-proclaim.my/journals/index.php/ajhal/issue/archive 